\title{
Impact of Combined Effect of Penetrating and Non-Penetrating Medium Components on Post-Hypertonic Lysis Development in Human Erythrocytes
}

\begin{abstract}
Реферат: Досліджували постгіпертонічний лізис еритроцитів людини при варіюванні складу середовища на етапі дегідратації. Осмоляльність комбінованих середовищ, які містять різні концентрації гліцерину і $\mathrm{NaCl}$, становила 2370 мОсм/л. Показано, що рівень постгіпертонічного лізису еритроцитів визначається не загальною осмоляльністю середовища дегідратації, а концентрацією гліцерину в складі комбінованих середовищ. Встановлено, що характер розвитку постгіпертонічного лізису еритроцитів за використання гліцерину в складі комбінованих середовищ на етапі дегідратації не залежить від попереднього насичення клітин кріопротектором. Порівняльне вивчення постгіпертонічного шоку еритроцитів за 37 і $0^{\circ} \mathrm{C}$ показало, що в останньому випадку гемоліз клітин розвивається за умов використання гліцерину в більш низькій концентрації (10\%) у складі комбінованих середовищ (при $0^{\circ} \mathrm{C}$ рівень постгіпертонічного лізису еритроцитів вище в 2,7 раза). Встановлений ефект може бути пов'язаний зі значною різницею в швидкостях транспорту води і кріопротектору через еритроцитарну мембрану при низькій температурі.

Ключові слова: постгіпертонічний шок, постгіпертонічний лізис, комбіновані середовища, гліцерин, еритроцити.

Abstract: In this research, a post-hypertonic lysis of human erythrocytes has been studied by varying the medium composition at dehydration stage. The osmolality of combined media, containing different concentrations of glycerol and $\mathrm{NaCl}$ was $\sim 2370 \mathrm{mOsm} / \mathrm{L}$. The level of post-hypertonic lysis of erythrocytes was shown as determined not by the total osmolality of dehydration medium, but glycerol concentration within the combined media. It was found that the nature of post-hypertonic lysis development of erythrocytes if using glycerol within the combined media at dehydration stage did not depend on preliminary cell saturation with cryoprotectant. A comparative study of post-hypertonic shock of erythrocytes at 37 and $0^{\circ} \mathrm{C}$ showed that in the latter case the cell hemolysis developed if using glycerol in lower concentration $(10 \%)$ within the combined media (at $0^{\circ} \mathrm{C}$ the level of erythrocyte post-hypertonic lysis was 2.7 times higher). The observed effect may be due to a significant difference in the rates of transport for water and cryoprotectant through erythrocyte membrane at low temperatures.
\end{abstract}

Key words: post-hypertonic shock, post-hypertonic lysis, combined media, glycerol, erythrocytes.

На сьогодні низькотемпературне консервування вважають єдиним можливим підходом, який забезпечує тривале зберігання крові та іiі компонентів [13, 16, 22]. За умов збереження еритроцитів при температурі $-196^{\circ} \mathrm{C}$ клітини зберігають свою цілісність, однак іх руйнування відбувається на етапах заморожування і розморожування внаслідок дії кріопошкоджувальних чинників $[10,13,16,22]$. Зміна температури та високі концентрації солей, що утворюються під час виморожування вільної води, мають руйнівний вплив на клітини у процесі заморожування. Цей ефект було вивчено 3 використанням модельних експериментів [6]. У процесі

Відділ кріоцитології, Інститут проблем кріобіології і кріомедицини НАН України, м. Харків
Today, the low-temperature preservation is considered as the only possible approach, providing a long-term storage for blood and its components [9, $12,19]$. When storing the erythrocytes at $-196^{\circ} \mathrm{C}$, their integrity is preserved, but during freezing and thawing, due to the effect of cryodamaging factors, their destruction occurs $[4,9,12,19]$. The temperature change and high concentrations of salts, formed within the free water freezing out, have a destroying effect on cells during freezing. This effect was studied using the model experiments [22]. During cell warming, as a result of ice melting, the medium osmolality is sharply decreased (from hypertonic values down to isotonic ones) and cell death can

Department of Cryocytology, Institute for Problems of Cryobiology and Cryomedicine of the National Academy of Sciences of Ukraine, Kharkiv, Ukraine
*Автор, якому необхідно надсилати кореспонденцію: вул. Переяславська, 23, м. Харків, Україна 61016; тел.: (+38 057) 373-74-35, фракс: (+38 057) 373-59-52 електронна пошта: chabanenkoolena@gmail.com

Надійшла 22.10.2019

Прийнята до друку 07.09.2020
*To whom correspondence should be addressed:

23, Pereyaslavska str., Kharkiv, Ukraine 61016;

tel.:+380 57373 7435, fax: +380 573735952

e-mail: chabanenkoolena@gmail.com

Received 22, October, 2019

Accepted 07, September, 2019

(c) 2020 O.O. Chabanenko, et al. Published by the Institute for Problems of Cryobiology and Cryomedicine

This is an Open Access article distributed under the terms of the Creative Commons Attribution License (http://creativecommons.org/licenses/by/4.0), which permits unrestricted reuse, distribution, and reproduction in any medium, provided the original work is properly cited. 
розморожування клітин внаслідок танення льоду осмоляльність середовища різко знижується (від гіпертонічних до ізотонічних значень), що може призводити до їх загибелі. Пошкодження еритроцитів за таких умов має назву постгіпертонічного шоку (ПГШ). Це явище можна реєструвати як у реальних умовах (у процесі розморожування клітин), так і в модельних експериментах $[2,3,21]$. У останньому випадку воно реалізується шляхом інкубації еритроцитів у середовищі дегідратації та їх подальшого перенесення в середовище регідратації за плюсових значень температури [2, 4].

На даний час 3 метою тривалого зберігання еритроцитів широко використовують їх низькотемпературне консервування під захистом гліцерину [13, 22]. Основне пошкодження клітин відбувається на етапі видалення кріопротектору, тому вдосконалення даного методу спрямовано на підвищення показників стану клітин на етапі його видалення [18, 19].

Результати застосування моделі ПГШ показали, що рівень постгіпертонічного лізису (ПГЛ) еритроцитів людини залежить від концентрацій проникального (гліцерин) і непроникального $(\mathrm{NaCl})$ компонентів $[2,5]$, тому важливо було визначити їх внесок в комбінованих середовищах у розвиток постгіпертонічного пошкодження еритроцитів людини.

Мета роботи - дослідження постгіпертонічного лізису еритроцитів людини при варіюванні концентрацій солі $(\mathrm{NaCl})$ та кріопротектору (гліцерин) за умов незмінної осмоляльності середовища дегідратації при 37 і $0^{\circ} \mathrm{C}$.

\section{Матеріали та методи}

У роботі використовували еритроцити, які отримували 3 донорської крові чоловіків А (II) групи, наданої Харківським обласним центром служби крові. Кров центрифугували, відбирали плазму, після еритромасу двічі відмивали на центрифузі (при 1000g) у 10-кратному об'ємі фізіологічного розчину $(0,9 \% \mathrm{NaCl})$, приготованому на фосфатному буфері, pH 7,4. Лейкоцитарну плівку і супернатант видаляли аспірацією. Еритроцити зберігали у вигляді щільного осаду не більше 4 годин за температури $0^{\circ} \mathrm{C}$. Усі середовища готували на фосфатному буфері (5 ммоль/л, pH 7,4). Вихідну суспензію еритроцитів отримували шляхом додавання осаду еритроцитів до фізіологічного розчину в співвідношенні $1: 1$.

Постгіпертонічний шок еритроцитів здійснювали наступним чином. Суспензію еритроцитів (200 мкл) переносили в 1,0 мл гіпертоніч- occur. The erythrocyte damage under such conditions is called as post-hypertonic shock (PHS). This phenomenon may be found both under real conditions (during cell freeze-thawing) and in model experiments $[18,20,21]$. In the latter case, it is implemented via erythrocyte incubation in dehydration medium and their subsequent transfer into rehydration one at positive temperature values [6, 20].

To date, the erythrocytes' low-temperature preservation with glycerol protection is commonly used for their long-term storage [9, 19]. The main cell damage occurs during cryoprotectant removal, so the mastering of this method is now focused to increase the indices of cell state during its removal $[14,15]$.

The results of application of PHS model showed the level of post-hypertonic lysis (PHL) of human erythrocytes to depend on concentrations of penetrating (glycerol) and non-penetrating $(\mathrm{NaCl})$ components $[7,20]$, therefore of importance was to determine their contribution within the combined media in development of post-hypertonic damage to human erythrocytes.

The research was aimed to study a post-hypertonic lysis of human erythrocytes by varying the concentrations of salt $(\mathrm{NaCl})$ and cryoprotectant (glycerol) under constant osmolality of dehydration medium at 37 and $0{ }^{\circ} \mathrm{C}$.

\section{Materials and methods}

The erythrocytes, procured from donated men blood of $\mathrm{A}(\mathrm{II})^{+}$group, provided by the Kharkiv Regional Blood Service Center, were used here. Blood was centrifuged, then the plasma was collected, and erythromass was washed twice by centrifugation (at 1000g) in 10-fold volume of saline $(0.9 \% \mathrm{NaCl}$ prepared with phosphate buffer, $\mathrm{pH}$ 7.4). Leukocyte film and supernatant were removed by aspiration. Erythrocytes were stored as a dense precipitate for no more than $4 \mathrm{hrs}$ at $0^{\circ} \mathrm{C}$. All the media were prepared with phosphate buffer (5 mmol/L, pH 7.4). The initial erythrocyte suspension was obtained by erythrocyte sediment supplement to saline in 1:1 ratio.

Post-hypertonic shock of erythrocytes was performed as follows: the erythrocyte suspension $(200 \mu \mathrm{l})$ was transferred into $1.0 \mathrm{ml}$ hypertonic solution, containing $7 \%(1.2 \mathrm{~mol} / \mathrm{L}) \mathrm{NaCl}$, then incubated for $20 \mathrm{~min}$ (dehydration stage). Afterwards, $50 \mu \mathrm{l}$ of suspension were taken from this sample and transferred into $1.0 \mathrm{ml}$ of saline (rehydration stage) for $5 \mathrm{~min}$. The final hematocrit made $0.4 \%$, the temperature regimen of experiment was 37 or $0^{\circ} \mathrm{C}$. 
ного розчину, що містить 7\% (1,2 моль/л) $\mathrm{NaCl}$, інкубували протягом 20 хв (етап дегідратації). Потім 3 цієї проби відбирали 50 мкл суспензії та переносили на 5 хв у 1,0 мл фізіологічного розчину (етап регідратації). Кінцевий гематокрит становив 0,4\%, температурний режим експерименту -37 або $0^{\circ} \mathrm{C}$.

Для вивчення ПГЛ еритроцитів із використанням гліцерину їх протягом 20 хв інкубували в середовищах, що містять різні концентрації гліцерину (2-15\%) та 0,9\% NaCl, після чого переносили в фізіологічний розчин на 5 хв (гематокрит $0,4 \%$ ). Температурний режим становив $37^{\circ} \mathrm{C}$.

Для визначення впливу складу середовища дегідратації на ПГЛ еритроцитів проводили їх інкубацію в комбінованих середовищах (етап дегідратації) і потім переносили в фізіологічний розчин (етап регідратації). У комбінованих середовищах вміст гліцерину та $\mathrm{NaCl}$ варіювали таким чином, щоб сумарна осмоляльність була незмінною і відповідала осмоляльності розчину, що містить 7\% NaCl (2370 мОсм/л). Склад використовуваних у роботі комбінованих середовищ із заданою осмоляльністю наведено в табл. 1.

Після завершення інкубації клітини центрифугували протягом 3 хв при 1000g. Вміст гемоглобіну, який вийшов у супернатант, визначали спектрофотометрично на довжині хвилі 543 нм. За 100\% приймали поглинання проби, до якої додавали детергент тритон X-100 у концентрації $0,1 \%$.

Схема проведення експерименту 3 вивчення ПГШ еритроцитів представлена на рис. 1.

Осмоляльність розчинів визначали за допомогою осмометра ОМКА 1Ц-01 («Медлабортехніка», Україна).

Для статистичної обробки отриманих експериментальних даних використовували програму «Statistica 6.0» (StatSoft Inc., США) і результати представляли як медіану (Me) i інтерквартільний інтервал (Q1-Q3). Статистичну значущість відмінностей досліджуваних числових показників перевіряли за критерієм Манна-Уїтні. Відмінності вважали значущими при $p<0,05$.

\section{Результати та обговорення}

Для вивчення впливу проникального кріопротектору гліцерину на ПГЛ еритроцитів проводили їх інкубацію в фізіологічних середовищах із різною концентрацією гліцерину, потім клітини переносили в фізіологічний розчин за $37^{\circ} \mathrm{C}$ (рис. 2). Видно, що рівень гемолізу еритроцитів різко збільшується при використанні гліцерину в концентраціях, що перевищують $2 \%$.
To study the erythrocytes' PHL with glycerol use, they were incubated in the media containing different concentrations of glycerol (2-15\%) and $0.9 \%$ $\mathrm{NaCl}$ for $20 \mathrm{~min}$, then transferred into saline for 5 min (hematocrit $0.4 \%$ ). Temperature regimen was $37^{\circ} \mathrm{C}$.

To determine the impact of the dehydration medium composition on erythrocytes' PHL, they were incubated in the combined media (dehydration stage) and then transferred into saline (rehydration stage). In the combined media, the glycerol and $\mathrm{NaCl}$ content was varied in such a way that the total osmolality of the solution remained constant and corresponded to the osmolality of the one, containing $7 \% \mathrm{NaCl}(2370 \mathrm{mOsm} / \mathrm{L})$. The composition of the combined media with a fixed osmolality we used here, was shown in the Table 1.

When incubation completed, the cells were centrifuged for $3 \mathrm{~min}$ at $1000 \mathrm{~g}$. The hemoglobin content, released into supernatant was determined spectrophotometrically at $543 \mathrm{~nm}$ wavelength. The absorption of the sample, supplemented with Triton $\mathrm{X}-100$ detergent at $0.1 \%$ concentration, was assumed as $100 \%$.

The design of the experiment on erythrocyte PHS study is shown in Fig. 1.

The osmolality of the solutions was determined using OMKA 1C-01 osmometer (Medlabortekhnyka, Ukraine).

Our findings were statistically processed with Statistica 6.0 software (StatSoft Inc., USA) and results presented as the median (Me) and interquartile range (Q1 - Q3). The significance of the differences in the studied numerical indices was analyzed using the Mann-Whitney test. The differences were considered significant at $p<0.05$.

\section{Results and discussion}

To study the impact of penetrating cryoprotectant glycerol on erythrocyte PHL, the cells were incubated in the salines with differently concentrated glycerol, then transferred into saline at $37^{\circ} \mathrm{C}$ (Fig. 2). The level of erythrocyte hemolysis was seen to be sharply increased with glycerol use in concentrations higher than $2 \%$. If a $5 \%$ cryoprotectant concentration causes the cell damage at the level of $70 \%$, then its further increase leads to almost complete lysis.

As established by E.A. Semionova et al. [20], the PHL level of mammalian erythrocytes under cell transferring from dehydration media, containing non-penetrating component (1.0-2.0 mol/L $\mathrm{NaCl})$ into rehydration one $(0.15 \mathrm{~mol} / \mathrm{L} \mathrm{NaCl})$ was determined by dehydration medium conditions. For example, a direct correlation between an increase 


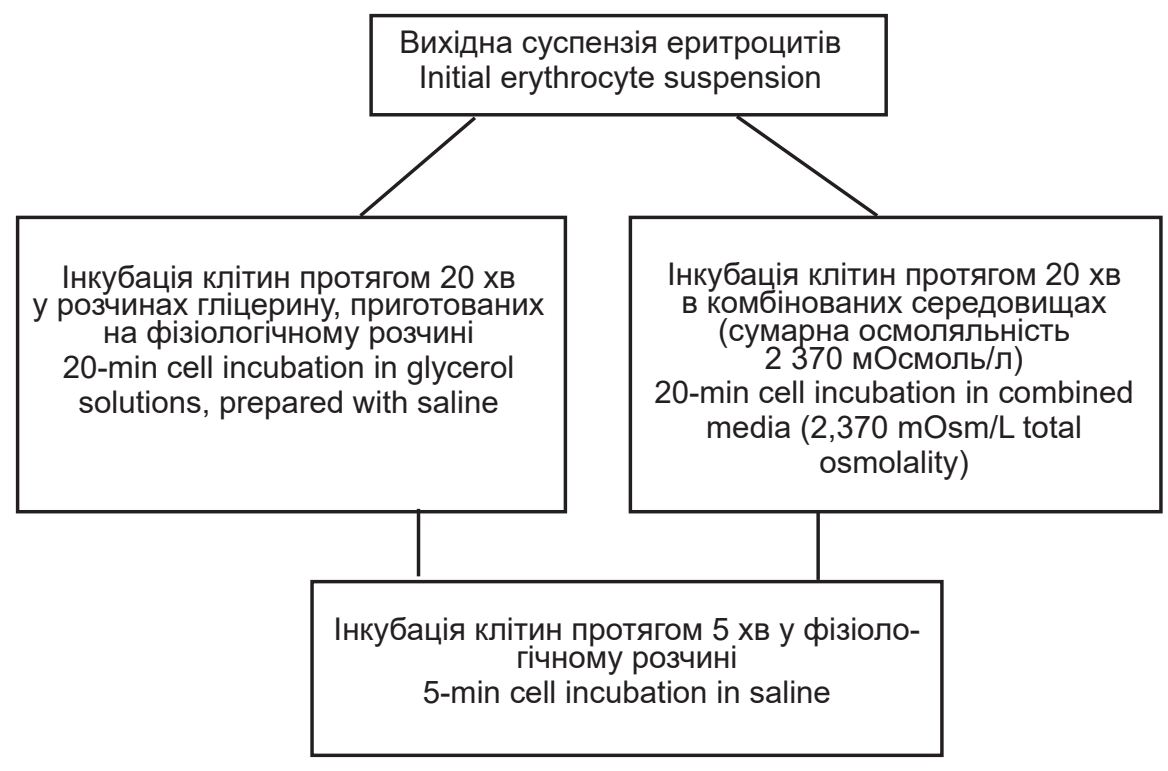

Рис. 1. Дизайн експерименту з вивчення ПГШ еритроцитів.

Fig. 1. Design of experiment on erythrocyte PHS study.

Якщо кріопротектор у концентрації 5\% викликає пошкодження клітин на рівні $70 \%$, то подальше iii підвищення призводить практично до повного лізису.

У дослідженні К. А. Сєміонової зі співавт. [2] встановлено, що рівень ПГЛ еритроцитів ссавців за умов перенесення клітин із середовищ дегідратації, що містять непроникальний компонент (1,0-2,0 моль/л $\mathrm{NaCl})$, у середовище регідратації $(0,15$ моль/л $\mathrm{NaCl})$ визначається умовами середовища дегідратації. Так, була встановлена пряма кореляція між підвищенням концентрації солі в середовищі дегідратації та рівнем пошкодження клітин після перенесення в середовище регідратації. Слід зазначити, що у середовищах дегідратації (які не перевищують 2,5 моль/л $\mathrm{NaCl}$ ) гемоліз еритроцитів не відбувається [6].

Виходячи 3 представлених на рис. 2 результатів та даних роботи К. А. Сєміонової та співавт. [2], можна зробити висновок, що дія проникального (гліцерину) та непроникального $(\mathrm{NaCl})$ компонентів може призводити до гемолізу еритроцитів при подальшому перенесенні в фізіологічні умови.

За умов кріоконсервування еритроцитів під захистом гліцерину на етапі розморожування на них одночасно діють проникальні та непроникальні компоненти. Для з'ясування залежності ПГЛ еритроцитів від осмоляльності середовища дегідратації, зумовленої присутністю проникальних i непроникальних компонентів, на етапі дегідратації за умов ПГШ еритроцитів використовували комбіновані середовища, що містять сіль та кріопротектор у різних співвідно- in salt concentration in dehydration medium and the level of cell damage after transferring into rehydration one was established. It should be noted that in dehydration media (not exceeding $2.5 \mathrm{~mol} / \mathrm{L} \mathrm{NaCl}$ ) no erythrocyte hemolysis occurred [22].

Proceeding from the results presented in Fig. 2 and as reported by E.A. Semionova etal. [20], we may conclude that the effect of penetrating and nonpenetrating components (glycerol and $\mathrm{NaCl}$, respectively) may entail the erythrocyte hemolysis during further transfer into physiologicals conditions.

Under conditions of erythrocyte cryopreservation with glycerol, during thawing, they are simultaneously affected by penetrating and non-penetrating components. To elucidate the dependence of erythrocyte PHL on the osmolality of dehydration medium, stipulated by the presence of penetrating and non-penetrating components, at dehydration stage under erythrocyte PHS were used the combined media, containing salt and cryoprotectant in different ratios, while the total osmolality of the medium remained unchanged (Table 1).

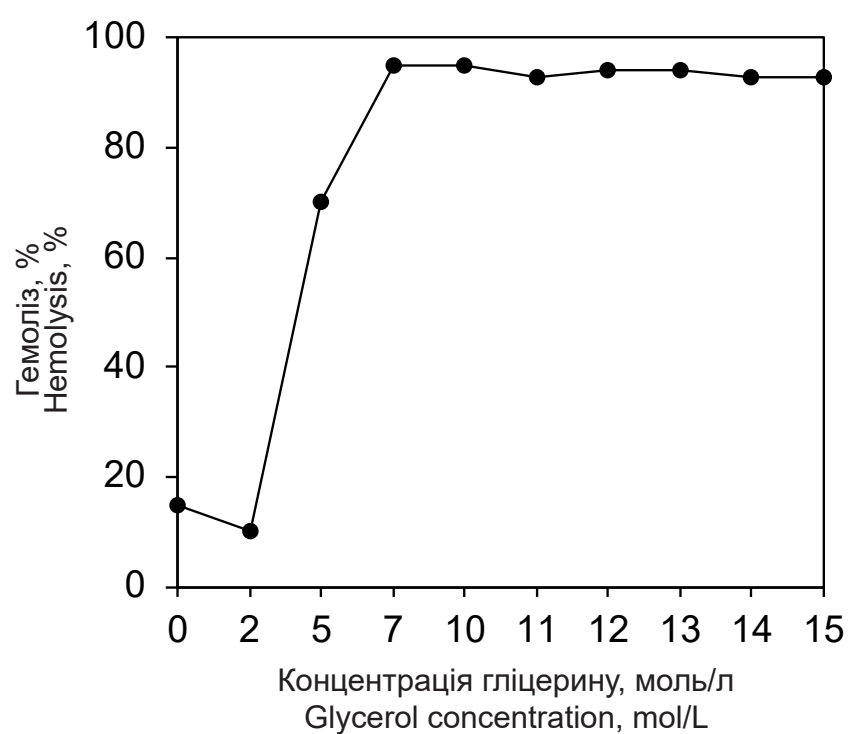

Рис. 2. Гемоліз еритроцитів, перенесених у середовище $0,9 \% \mathrm{NaCl}$ з фрізіологічного розчину, який містить гліцерин у різних концентраціях $\left(37^{\circ} \mathrm{C}\right)$.

Fig. 2. Hemolysis of erythrocytes, transferred into $0.9 \%$ $\mathrm{NaCl}$ solution from saline, containing glycerol in various concentrations $\left(37^{\circ} \mathrm{C}\right)$. 
Таблиця 1. Склад комбінованих середовищ (сумарна осмоляльність 2370 мОсм/л)

Table 1. Combined media composition (2370 mOsm/L total osmolality)

\begin{tabular}{|c|c|c|c|c|c|c|}
\hline \multirow{3}{*}{$\begin{array}{l}\text { Середовище } \\
\text { Medium }\end{array}$} & \multicolumn{3}{|c|}{$\begin{array}{l}\text { Гліцерин } \\
\text { Glycerol }\end{array}$} & \multicolumn{3}{|c|}{$\begin{array}{l}\text { Хлорид натрію } \\
\text { Sodium chloride }\end{array}$} \\
\hline & \multicolumn{2}{|c|}{$\begin{array}{l}\text { Концентрація } \\
\text { Concentration }\end{array}$} & \multirow{2}{*}{$\begin{array}{c}\begin{array}{c}\text { Oсмоляльність } \\
\text { Osmolality }\end{array} \\
\text { MOcm/л } \\
\mathrm{mOsm} / \mathrm{L}\end{array}$} & \multicolumn{2}{|c|}{$\begin{array}{l}\text { Концентрація } \\
\text { Concentration }\end{array}$} & \multirow{2}{*}{$\begin{array}{c}\begin{array}{c}\text { Oсмоляльність } \\
\text { Osmolality }\end{array} \\
\begin{array}{l}\text { мOcm/r } \\
\mathrm{mOsm} / \mathrm{L}\end{array}\end{array}$} \\
\hline & $\%$ & $\begin{array}{c}\text { моль/л } \\
\mathrm{mol} / \mathrm{L}\end{array}$ & & $\%$ & $\begin{array}{c}\text { моль/л } \\
\mathrm{mol} / \mathrm{L}\end{array}$ & \\
\hline 1 & - & - & - & 7 & 1,2 & 2370 \\
\hline 2 & 2 & 0,22 & 236 & 6,2 & 1,06 & 2134 \\
\hline 3 & 5 & 0,54 & 656 & 5 & 0,86 & 1714 \\
\hline 4 & 7 & 0,76 & 940 & 4,2 & 0,71 & 1430 \\
\hline 5 & 10 & 1,09 & 1370 & 2,9 & 0,5 & 1000 \\
\hline 6 & 11 & 1,19 & 1510 & 2,5 & 0,43 & 860 \\
\hline 7 & 12 & 1,30 & 1670 & 2,0 & 0,35 & 700 \\
\hline 8 & 13 & 1,41 & 1810 & 1,6 & 0,28 & 560 \\
\hline 9 & 14 & 1,52 & 1945 & 1,2 & 0,21 & 425 \\
\hline 10 & 15 & 1,63 & 2070 & 0,9 & 0,15 & 300 \\
\hline
\end{tabular}

шеннях, але при цьому сумарна осмоляльність середовища була незмінною (табл. 1).

3 представлених на рис. 3 даних видно, що рівень ПГЛ еритроцитів у середовищі, яке містить $7 \% \mathrm{NaCl}$ (середовище 1, контроль), становить приблизно $15 \%$, а гліцерин у низьких концентраціях (середовища 2-5) практично не впливає на рівень гемолізу еритроцитів, але в концентрації 11\% (середовище 6) призводить до різкого його зростання.

Отже, рівень ПГЛ еритроцитів при використанні комбінованих середовищ на етапі дегідратації залежить від концентрації кріопротектору, а не від загальної осмоляльності середовища дегідратації.

Порівняльний аналіз даних, поданих на рис. 2 i 3, показав, що пошкоджувальна дія гліцерину (у складі комбінованих середовищ) проявляється при його високих концентраціях (11\% і вище), а за концентрації 5-10\% (у відповідних концентраціях солі у середовищах 3-5) він практично не викликає додаткового ПГЛ еритроцитів порівняно 3 контролем.

Виникає питання, чому в складі комбінованих середовищ 3-5 гліцерин у концентрації 5$10 \%$ не пошкоджує клітини за умов ПГШ порівняно $з$ використанням гліцерину, який готували на фізіологічному розчині. Можна припустити,
The data presented in Fig. 3 showed that the level of erythrocyte PHL in the medium containing 7\% $\mathrm{NaCl}$ (medium 1, control) was approximately 15\%, and glycerol at low concentrations (medium 2-5) did not virtually affect the level of erythrocyte hemolysis, but in 11\% concentration (medium 6) it resulted in a sharp increase in cell damage.

Thus, the PHL level of erythrocytes when using the combined media at dehydration stage depends on cryoprotectant concentration, but not on total osmolality of dehydration medium.

Comparative analysis of the data presented in Fig. 2 and 3, showed a damaging effect of glycerol (within the combined media) as manifested under its high concentrations ( $11 \%$ and higher), but at $5-10 \%$ one (at appropriate salt concentrations in the media 3-5), it virtually did not cause an additional PHL of erythrocytes as compared with the control.

The question arises why within the combined media $3-5$ the $5-10 \%$ glycerol causes no damage to cells under PHS as compared with glycerol, prepared with saline. The presence of salt component within the combined media at dehydration stage may be assumed to affect the cell saturation with glycerol.

To verify this assumption, the cells were presaturated for $20 \mathrm{~min}$ with glycerol at $37^{\circ} \mathrm{C}$, and then subjected to PHS using combined media at dehydration stage (Fig. 4). We noted that the nature of 
що присутність на етапі дегідратації сольового компонента у складі комбінованих середовищ впливає на процес насичення клітин гліцерином.

Для перевірки цього припущення клітини попередньо насичували протягом 20 хв гліцерином за $37^{\circ} \mathrm{C}$, а потім піддавали дії ПГШ із використанням комбінованих середовищ на етапі дегідратації (рис. 4). Видно, що характер розвитку ПГЛ еритроцитів за вказаних умов не відрізняється від такого після використання гліцерину в складі комбінованих середовищ тільки на етапі дегідратації (див. рис. 3).

Залишається відкритим питання стосовно того, чому при використанні гліцерину в діапазоні концентрацій 5-10\% (середовища 3-5) ПГЛ еритроцитів тримається на рівні контролю. Можливо, що цей ефект пов'язаний зі зміною стану еритроцитарної мембрани в присутності солі та гліцерину.

Для спрямованої зміни стану мембрани експеримент за умов ПГШ еритроцитів із використанням комбінованих середовищ проводили при $0^{\circ} \mathrm{C}$ (попереднє насичення гліцерином здійснювали за $\left.37^{\circ} \mathrm{C}\right) .3$ даних в табл. 2 видно, що характер розвитку ПГЛ еритроцитів за $0^{\circ} \mathrm{C}$ аналогічний такому, що і за $37^{\circ} \mathrm{C}$. Гліцерин у концентрації $2-7 \%$ не викликає додаткового пошкодження еритроцитів за умов ПГШ (середовища 2-4) при $0^{\circ} \mathrm{C}$, що характерно і для температурного режиму $37^{\circ} \mathrm{C}$.

При різних температурних режимах за умов ПГШ еритроцитів спостерігаються відмінності результатів після використання гліцерину в концентрації 10\% (середовище 5). У цьому випадку



Рис. 3. Гемоліз еритроцитів, перенесених у розчин $0,9 \%$ $\mathrm{NaCl}$ із комбінованих середовищ, які містять гліцерин i $\mathrm{NaCl}$ у різних концентраціях $\left(37^{\circ} \mathrm{C}\right)$.

Fig. 3. Hemolysis of erythrocytes, transferred into $0.9 \%$ $\mathrm{NaCl}$ solution from combined media, containing glycerol and $\mathrm{NaCl}$ in different concentrations $\left(37^{\circ} \mathrm{C}\right)$.

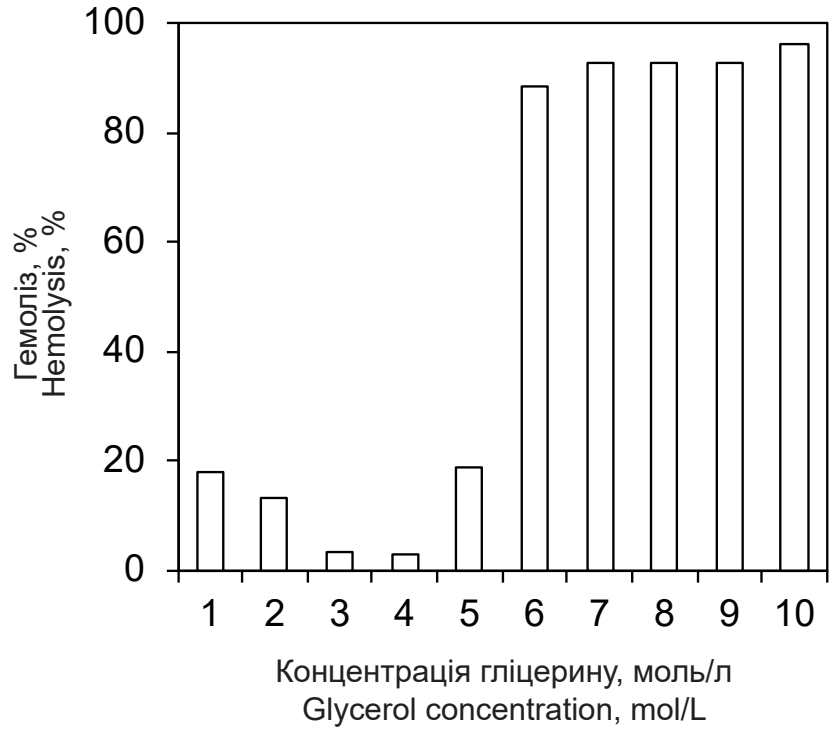

Рис. 4. Вплив попередньої обробки клітин гліцерином на рівень гемолізу еритроцитів, перенесених у розчин $0,9 \% \mathrm{NaCl}$, із комбінованих середовищ $\left(37^{\circ} \mathrm{C}\right)$.

Fig. 4. Impact of cell pre-treatment with glycerol on hemolysis level of erythrocytes transferred into $0.9 \% \mathrm{NaCl}$ solution from combined media $\left(37^{\circ} \mathrm{C}\right)$.

erythrocyte PHL development under these conditions did not differ from that after glycerol use within the combined media at dehydration stage only (see Fig. 3).

The issue is still open why the erythrocyte PHL remains at the control level when using glycerol within the concentration range of $5-10 \%$ (medium $3-5$ ). This effect may be associated with a change in erythrocyte membrane state in salt and glycerol presence.

For a targeted change in membrane state, the experiment was carried out under erythrocyte PHS using the combined media at $0^{\circ} \mathrm{C}$ (pre-saturation with glycerol was performed at $37^{\circ} \mathrm{C}$ ). The Table 2 data showed the nature of erythrocyte PHL development at $0^{\circ} \mathrm{C}$ to be similar to that at $37^{\circ} \mathrm{C}$. Glycerol at $2-7 \%$ concentration caused no additional damage to erythrocytes under PHS (medium 2-4) at $0^{\circ} \mathrm{C}$, that was typical for temperature regimen of $37^{\circ} \mathrm{C}$.

Under different temperature regimens of erythrocyte PHS, the differences in results were observed after using 10\% glycerol (medium 5). In this case, at low temperature, the level of erythrocyte PHL was 2.7 times higher.

To design the efficient cryopreservation procedures for cells, it is necessary to investigate the process of their osmotic destruction, resulting from the effect of cryoinjury factors of erythrocytes.

Osmotic damages to erythrocytes occur when the cell volume reaches a critical value. The nature of such changes depends on erythrocyte membrane 
при низькій температурі рівень ПГЛ еритроцитів вище в 2,7 раза.

Для розробки ефективних процедур кріоконсервування клітин необхідно вивчення процесу їх осмотичного руйнування, внаслідок дії факторів кріопошкоджень еритроцитів.

Осмотичне пошкодження еритроцитів відбувається в тому випадку, коли об'єм клітин досягає критичного значення. Характер таких змін залежить від проникності еритроцитарної мембрани для речовин: води та проникальних кріопротекторів. Тому для розробки ефективних протоколів кріоконсервування конкретних видів клітин необхідні дані щодо проникності клітинної мембрани для води та розчинених речовин.

Відомо, що проникність еритроцитарної мембрани для води залежить не тільки від індивідуальних особливостей донора, методів отримання еритроцитів, але і від терміну зберігання клітин перед процедурою заморожування [7, 8]. Транспорт води через еритроцитарну мембрану є складним процесом і може відбуватися декількома шляхами: через ліпідний бішар, UT-B, аквапоріни 1 i 3 [17]. Інформація відносно часткового внеску кожного 3 вищеописаних шляхів $\epsilon$ досить суперечливою, проте більшість дослідників вважають, що близько 90\% транспорту води здійснюється через аквапорін 1, а біля 10\% іншими шляхами [20].

У процесі перенесення гліцерину через еритроцитарну мембрану бере участь аквапорін 3 [17], який на рівні 2\% є проникальним і для молекул води, але в цілому можна вважати, що більшість потоків води та гліцерину не буде взаємодіяти, оскільки вони перетинають мембрану переважно різними шляхами.

Вода проникає через мембрану швидше за всі відомі кріопротектори. Причиною виникнення потоків води всередину та 3 клітини є градієнт осмотичного тиску на мембрані, який, у свою чергу, визначається сумарною концентрацією розчинених речовин у позаклітинному середовищі та в клітині. Врівноваження цих концентрацій призводить до припинення потоків.

Осмотичну реакцію еритроцитів можна розділити на два етапи: перенесення води та проникального кріопротектору. Це обумовлено відмінностями проникності еритроцитарної мембрани для цих речовин. Спочатку, внаслідок циркуляції води, врівноважуються концентрації розчинених речовин зовні та всередині клітини, а потім шляхом дифузії вирівнюються позаi внутрішньоклітинні концентрації гліцеринy.
Таблиця 2. Вплив температури на гемоліз еритроцитів, перенесених у розчин $0,9 \% \mathrm{NaCl}$ із комбінованих середовищ після попередньої обробки клітин гліцерином (Me, Q1-Q3, $n=7$ )

Table 2. Effect of temperature on hemolysis of erythrocytes, transferred into $0.9 \% \mathrm{NaCl}$ solution from combined media after preliminary cell treatment with glycerol (Me, Q1-Q3, $n=7$ )

\begin{tabular}{|c|c|c|}
\hline \multirow{3}{*}{$\begin{array}{l}\text { Середовище } \\
\text { Medium }\end{array}$} & \multicolumn{2}{|c|}{$\begin{array}{l}\text { Гемоліз, \% } \\
\text { Hemolysis, \% }\end{array}$} \\
\hline & \multicolumn{2}{|c|}{$\begin{array}{l}\text { Температурний режим ПГШ, }{ }^{\circ} \mathrm{C} \\
\text { Temperature regimen of } \mathrm{PHS},{ }^{\circ} \mathrm{C}\end{array}$} \\
\hline & 37 & 0 \\
\hline 1 & $19(18-21)$ & $14(10-20)$ \\
\hline 2 & $13(12-14)$ & $12(8-15)$ \\
\hline 3 & $3(2-4)$ & $3(1-5)$ \\
\hline 4 & $3(1-3)$ & $4(2-7)$ \\
\hline 5 & $19(11-29)$ & $63 *(53-80)$ \\
\hline 6 & $88(85-94)$ & $95 *(94-97)$ \\
\hline 7 & $93(92-95)$ & $97(96-98)$ \\
\hline
\end{tabular}

Примітка: * - відмінності значущі порівняно з показниками при $37^{\circ} \mathrm{C}(p<0,05)$.

Note: * differences are significant if compared with $37^{\circ} \mathrm{C}$, $p<0.05$.

permeability to substances: water and penetrating cryoprotectants. Therefore, the development of efficient cryopreservation protocols for specific cell types requires the data on cell membrane permeability to water and solutes.

The erythrocyte membrane permeability to water is known to be dependent not only on individual characteristics of donor, techniques for erythrocyte procurement, but on storage term of cells prior to freezing as well $[1,2]$. The water transport through erythrocyte membrane is a complex process and it may occur in several ways: through lipid bilayer, UT-B, aquaporins 1 and 3 [13]. The information on a partial contribution of each of the above pathways is quite a contradictory, but most researchers believe that about $90 \%$ of water transport is realized via aquaporin 1 , and about $10 \%$ by other pathways [16].

Glycerol transport through erythrocyte membrane is realized by aquaporin 3 [13], which also conducts $2 \%$ of water, but, generally, it is believed that most water and glycerol flows will not interact because they cross membrane in different ways. 
Виявлений у роботі ефект розвитку ПГЛ еритроцитів після використання гліцерину в концентрації 5\% і вище (див. рис. 2) пов'язаний зі значним входом води в клітини на етапі регідратації (через градієнт осмотичного тиску на мембрані, обумовлений внутрішньоклітинним вмістом гліцерину) i, як наслідок, досягненням критичного гемолітичного об'єму еритроцитів.

Використання на етапі дегідратації кріопротектору в складі комбінованих середовищ 3-5, які містять (5-10\% гліцерину і $5-2,9 \% \mathrm{NaCl}$ ) (див. рис. 3), практично не викликає постгіпертонічного пошкодження еритроцитів на відміну від гліцерину (5-10\%), приготованому на фізіологічному розчині (див. рис. 2). Можливо, зневоднення клітин за умов використання вищевказаних комбінованих середовищ супроводжується меншим входом у них гліцерину, тому зміна об'єму еритроцитів (у результаті входу води на етапі регідратації) не досягає критичних значень i не супроводжується їх руйнуванням. Крім того, зниження вмісту гліцерину у зневоднених клітинах C.X. Межидов та співавт. [1] пов'язують із впливом внутрішньоклітинної концентрації білка (переважно представленого гемоглобіном) на проникність еритроцитарної мембрани для гліцерину.

Після попередньої обробки клітин гліцерином (5-10\%) у разі використання комбінованих середовищ 3-5, які містять гліцерин (5-10\%) i $\mathrm{NaCl}$ (5-2,9\%) рівень ПГЛ клітин не збільшується (див. рис. 4). Цей ефект, імовірно, зумовлений виходом гліцерину з клітин услід за водою на етапі дегідратації, в результаті сумарний вміст внутрішньоклітинних компонентів практично сумірний 3 таким без попередньої обробки клітин. Саме тому в обох варіантах експерименту з ПГШ відсутні статистично значущі відмінності рівня ПГЛ еритроцитів.

Порівняльне вивчення ПГЛ еритроцитів за температур 37 i $0^{\circ} \mathrm{C}$ (табл. 2) показало, що в останньому випадку пошкодження розвивається за умов використання гліцерину в більш низькій концентрації - 10\% (середовище 5). Відомо, що проникність плазматичної мембрани клітин при низькій температурі знижується як для води, так і для гліцерину, причому для останнього більшою мірою $[9,14,15]$.

Високий рівень ПГЛ еритроцитів $\left(0^{\circ} \mathrm{C}\right)$ за умов використання комбінованого середовища 5 $(10 \%$ гліцерину і $2,9 \% \mathrm{NaCl})$, ймовірно, зумовлений значною різницею в швидкостях транспорту води і кріопротектору через еритроцитарну мембрану. На етапі регідратації ці клітини (порівняно з $37^{\circ} \mathrm{C}$ ) зазнають більш значних змін і досягають
The water penetrates through a membrane more rapidly than all the known cryoprotectants. The processes of water entering the cell and leaving it are caused by the osmotic pressure gradient on the membrane, which, in turn, is determined by the total concentration of the solutes in extracellular medium and in a cell. When these concentrations are equilibrated, the flows are stopped.

An osmotic response of erythrocytes may be divided into two stages: transport of water and penetrating cryoprotectant. This is stipulated by differences in erythrocyte membrane permeability to these substances. First, due to water circulation, the concentrations of solutes outside and inside the cell are balanced, and then the extra- and intracellular glycerol concentrations are equalized by diffusion.

The effect of erythrocyte PHL development after glycerol use of 5\% concentration and higher (see Fig. 2) is associated with a significant entry of water into the cells at rehydration stage (through the osmotic pressure gradient on a membrane due to the intracellular glycerol content) and as a consequence, the achievement of critical hemolytic volume of erythrocytes.

The use of cryoprotective agent within the combined media $3-5$, containing (5-10\% glycerol and 5$2.9 \% \mathrm{NaCl}$ ) (see Fig. 3) at dehydration stage scarcely causes a post-hypertonic damage to erythrocytes in contrast to glycerol (5-10\%) prepared with saline (see Fig. 2). The dehydration of cells when using the above combined media is possibly accompanied by a less entry of glycerol into them, therefore the change in erythrocytes' volume (as a result of water entry at rehydration stage) does not reach the critical values and is not accompanied by their destruction. In addition, C.Kh. Mezhidov et al. [17] associated the reduction of glycerol content in dehydrated cells with the impact of intracellular protein concentration (mostly presented by hemoglobin) on the erythrocyte membrane permeability for glycerol.

After cell pre-treatment with glycerol (5-10\%) when using the combined media $3-5$, containing glycerol $(5-10 \%)$ and $\mathrm{NaCl}(5-2.9 \%)$, the cell PHL level does not increase (see Fig. 4). This effect is probably due to the glycerol release from cells following the water at dehydration stage, as a result the total content of intracellular components is almost comparable with that free of cell pre-treatment. That is why in both versions of the experiment with PHS no significant differences in the erythrocyte PHL level were present.

A comparative study of erythrocyte PHL at 37 and $0^{\circ} \mathrm{C}$ (Table 2) showed the damage in the latter 
значень критичного гемолітичного об'єму, внаслідок чого вони піддаються лізису.

В огляді J.M. Lahmann та співавт. [17] наведено численні дані щодо проникності клітинної мембрани для води та гліцерину, які свідчать про iii залежність від концентрації розчиненої речовини. А. Carlsen та співавт. [11] встановили суттєве зниження (більш ніж в 5 разів) проникності еритроцитарної мембрани для гліцерину в концентрації до 4 моль/л. Проте результати, отримані для кріопротекторів у концентрації менше за 2 моль/л (що відповідає умовам нашої роботи), досить суперечливі $[12,23]$, тому питання щодо проникності клітинної мембрани за умов використання кріопротекторів у низьких концентраціях потребує більш ретельного вивчення.

Таким чином, результати роботи важливі для розуміння процесів, що відбуваються за умов ПГШ еритроцитів із використанням комбінованих середовищ, на основі проникального (гліцерин) і непроникального (сіль) компонентів.

Результати подальших досліджень у цьому напрямку можуть бути підгрунтям для розробки протоколів низькотемпературного консервування еритроцитів 3 метою поліпшення показників їх стану на етапі видалення проникального кріопротектору.

\section{Висновки}

1. Встановлено, що рівень ПГЛ еритроцитів i3 використанням на етапі дегідратації комбінованих середовищ на основі гліцерину і хлориду натрію із сумарною осмоляльністю 2370 мОсм/л, залежить від концентрації кріопротектору, тобто рівень ПГЛ еритроцитів не визначається загальною осмоляльністю середовища дегідратації.

2. Показано, що характер розвитку ПГЛ еритроцитів за умов використання гліцерину в складі комбінованих середовищ на етапі дегідратації не залежить від попереднього насичення клітин кріопротектором.

3. Порівняльне вивчення ПГШ еритроцитів при температурах 37 i $0^{\circ} \mathrm{C}$ показало відмінності рівня гемолізу еритроцитів за умов використання комбінованого середовища (10\% гліцерину і 2,9\% $\mathrm{NaCl})$ : при низькій температурі рівень ПГЛ еритроцитів був вище в 2,7 раза.

\section{Література}

1. Межидов CX, Моисеев ВА. Влияние концентрации внутриклеточного гемоглобина на проницаемость эритроцитов. Проблемы криобиологии. 1995; (4): 50-1. case to be in progress when using the lower concentrated glycerol: $10 \%$ (medium 5). It is known that at low temperature the plasma membrane permeability of cells decreases for both water and glycerol, moreover, to a greater extent for the latter $[3,10,11]$.

When using the combined medium $5(10 \%$ glycerol and $2.9 \% \mathrm{NaCl}$ ), a high level of erythrocyte PHL $\left(0^{\circ} \mathrm{C}\right)$ was probably stipulated by a significant difference in the water and cryoprotectant transport rates through erythrocyte membrane. At rehydration stage, these cells (compared to $37^{\circ} \mathrm{C}$ ) underwent more significant changes and reached the values of critical hemolytic volume, resulting in their lysis.

The J.M. Lahmann et al. review [13] provided the numerous data on the cell membrane permeability to water and glycerol, testifying to its dependence on solute concentration. A. Carlsen et al. [5] have found a significant decrease (more than 5 times) in the erythrocyte membrane permeability for glycerol at a concentration below $4 \mathrm{~mol} / \mathrm{L}$. However, the findings obtained for cryoprotective agents at a concentration lower than $2 \mathrm{~mol} / \mathrm{L}$ (that corresponds to our research conditions) are quite contradictory $[8,23]$, therefore the question of cell membrane permeability when using the low concentrated cryoprotectants, requires more detailed study.

Thus, our findings are important for understanding the processes, occurring under erythrocyte PHS if using the combined media, based on penetrating (glycerol) and non-penetrating (salt) components.

The further findings in this direction may be the reason to design the protocols for low-temperature erythrocyte preservation to improve the indices of their state during penetrating cryoprotectant removal.

\section{Conclusions}

1. The erythrocyte PHL level was established to depend on cryoprotectant concentration, if using the glycerol- and sodium chloride-based combined media with $2370 \mathrm{mOsm} / \mathrm{L}$ total osmolality at dehydration stage, $i$. e. the erythrocyte PHL level was not determined by total osmolality of dehydration medium.

2. The nature of erythrocytes PHL development when using glycerol within the combined media at dehydration stage was shown as not depending on preliminary cell saturation with cryoprotectant.

3. A comparative study of erythrocyte PHS at 37 and $0^{\circ} \mathrm{C}$ demonstrated the differences in the erythrocyte hemolysis level when using the combined medium $(10 \%$ glycerol and $2.9 \% \mathrm{NaCl}), i$. e . at low temperature the erythrocyte PHL level was 2.7 times higher. 
2. Семионова ЕА, Ершова НА, Ершов СС, и др. Особенности проявления постгипертонического лизиса эритроцитов некоторых млекопитающих. Проблеми кріобіології і кріомедицини. 2016; 26(1): 73-83.

3. Семионова ЕА, Землянских НГ, Орлова НВ, Шпакова НМ Антигемолитическая эффективность хлорпромазина в условиях постгипертонического шока и при удалении глицерина из эритроцитов после размораживания. Проблеми кріобіології і кріомедицини. 2017; 27(1): 51-60.

4. Чабаненко EA, Семионова EA, Шпакова НМ. Хлорпромазин и постгипертонический шок как модель повреждения криоконсервированных клеток при их отогреве. Проблеми кріобіології і кріомедицини. 2017; 27(2): 161.

5. Чабаненко ЕА, Шапкина ОА, Орлова НВ, Шпакова НМ. Влияние глицерина на постгипертонический шок эритроцитов. Вісник проблем біології і медицини. 2018; (143): 379-82.

6. Шпакова НМ, Орлова НВ, Ершов СС, Бондаренко ВА. Влияние хлорпромазина на осмотическую и температурную чувствительность эритроцитов и на структурно-динамическое состояние эритроцитарных мембран. В: Гольцев АН, редактор. Актуальные проблемы криобиологии и криомедицины. Харьков: ИПКиК НАН Украины; 2012. с. 20728.

7. Alshalani A, Acker JP. Red blood cell membrane water permeability increases with length of ex vivo storage. Cryobiology. 2017; 76: 51-8

8. Alshalani A, Howell A, Acker JP. Impact of blood manufacturing and donor characteristics on membrane water permeability and in vitro quality parameters during hypothermic storage of red blood cells. Cryobiology. 2018; 80: 30-7

9. Benga G, Borza T. Diffusional water permeability of mammalian red blood cells. Comp Biochem Physiol B Biochem Mol Biol. 1995; 112(4): 653-9.

10.Capicciotti CJ, Kurach JD, Turner TR, et al. Small molecule ice recrystallization inhibitors enable freezing of human red blood cells with reduced glycerol concentrations. Sci Rep. [Internet]. 2015 [cited 7.10.2019]; 5: 9692. Available from: https://www. nature.com/articles/srep09692\#citeas

11.Carlsen A, Wieth JO. Glycerol transport in human red cells. Acta Physiol Scand. 1976; 97(4): 501-13.

12.EImoazzen HY, Elliott JA, McGann E. Osmotic transport across cell membranes in nondilute solutions: a new nondilute solute transport equation, Biophys J. 2009; 96(7): 2559-71.

13.Fuller BJ, Lane N, Benson EE editors. Life in the frozen state. Boca Raton: CRC: Press; 2004. 672 p.

14.Gilmore JA, Mcgann LE, Liu J, et al. Effect of cryoprotectant solutes on water permeability of human spermatozoa. Bio Reproduction. 1995; 53(5): 985-95.

15.Gordienko OI, Kovalenko SYe, Kovalenko IF. Mechanisms of glycerol permeability through the membrane of human erythrocytes. Problems of Cryobiology. 2012; 22(4): 389-97.

16.Lagerberg JW. Cryopreservation of red blood cells. Methods Mol Biol. 2015; 1257: 353-67.

17.Lahmann JM, Benson JD, Higgins AZ. Concentration dependence of the cell membrane permeability to cryoprotectant and water and implications for design of methods for postthaw washing of human erythrocytes. Cryobiology. 2018; 80: 1-11.

18.Lelkens CC, de Korte D, Lagerberg JW. Prolonged postthaw shelf life of red cells frozen without prefreeze removal of excess glycerol. Vox Sang. 2015; 108(3): 219-25.

19.Lusianti RE, Benson JD, Acker JP, Higgins AZ. Rapid removal of glycerol from frozen-thawed red blood cells. Biotechnol Prog 2013; 29(3): 609-20.

20.Mathai JC, Mori S, Smith BL, et al. Functional analysis of aquaporin-1 deficient red cells. The Colton-null phenotype. J Biol Chem. 1996; 271(3): 1309-13.

21.Muldrew K. The salting-in hypothesis of post-hypertonic lysis Cryobiology. 2008; 57(3): 251-6.

22.Pegg DE. Principles of cryopreservation. Methods Mol Biol. 2015;1257: 3-19.

\section{References}

1. Alshalani A, Acker JP. Red blood cell membrane water permeability increases with length of ex vivo storage. Cryobiology. 2017; 76: 51-8.

2. Alshalani A, Howell A, Acker JP. Impact of blood manufacturing and donor characteristics on membrane water permeability and in vitro quality parameters during hypothermic storage of red blood cells. Cryobiology. 2018; 80: 30-7.

3. Benga G, Borza T. Diffusional water permeability of mammalian red blood cells. Comp Biochem Physiol B. 1995; 112(4): 6539.

4. Capicciotti CJ, Kurach JD, Turner TR, et al. Small molecule ice recrystallization inhibitors enable freezing of human red blood cells with reduced glycerol concentrations. Sci Rep. [Internet]. 2015 [cited 7.10.2019]; 5: 9692. Available from: https://www. nature.com/articles/srep09692\#citeas

5. Carlsen A, Wieth JO. Glycerol transport in human red cells. Acta Physiol Scand. 1976; 97(4): 501-13.

6. Chabanenko OO, Semionova EA, Shpakova NM. Chlorpromazine and posthypertonic stress as model of damage in cryopreserved cells during thawing. Probl Cryobiol Cryomed. 2017; 27(2): 161

7. Chabanenko OO, Shapkina OO, Orlova NV, Shpakova NM. [Glycerol effect on posthypertonic shock of erythrocytes]. Visnyk Problem Biologii i Medycyny. 2018; (143): 379-82. Russian.

8. Elmoazzen HY, Elliott JA, McGann E. Osmotic transport across cell membranes in nondilute solutions: a new nondilute solute transport equation. Biophys J. 2009; 96(7): 2559-71.

9. Fuller BJ, Lane N, Benson EE editors. Life in the frozen state. Boca Raton: CRC: Press; 2004. 672 p.

10.Gilmore JA, Mcgann LE, Liu J, et al. Effect of cryoprotectant solutes on water permeability of human spermatozoa. Biol Reproduction. 1995; 53(5): 985-95.

11.Gordienko OI, Kovalenko SYe, Kovalenko IF. Mechanisms of glycerol permeability through the membrane of human erythrocytes. Problems of Cryobiology. 2012; 22(4): 389-97.

12.Lagerberg JW. Cryopreservation of red blood cells. Methods Mol Biol. 2015; 1257: 353-67.

13.Lahmann JM, Benson JD, Higgins AZ. Concentration dependence of the cell membrane permeability to cryoprotectant and water and implications for design of methods for postthaw washing of human erythrocytes. Cryobiology. 2018; 80: 111.

14.Lelkens CC, de Korte D, Lagerberg JW. Prolonged postthaw shelf life of red cells frozen without prefreeze removal of excess glycerol. Vox Sang. 2015; 108(3): 219-25.

15.Lusianti RE, Benson JD, Acker JP, Higgins AZ. Rapid removal of glycerol from frozen-thawed red blood cells. Biotechnol Prog. 2013; 29(3): 609-20.

16.Mathai JC, Mori S, Smith BL, et al. Functional analysis of aquaporin-1 deficient red cells. The Colton-null phenotype. J Biol Chem. 1996; 271(3): 1309-13.

17.Mezhidov CKh, Moiseyev VA. [The effect of concentration of the intracellular hemoglobin on the permeability of red blood cells]. Problems of Cryobiology. 1995; (4): 50-1. Russian.

18.Muldrew K. The salting-in hypothesis of post-hypertonic lysis. Cryobiology. 2008; 57(3): 251-6.

19.Pegg DE. Principles of cryopreservation. Methods Mol Biol. 2015;1257: 3-19.

20. Semionova EA, Yershova NA, Yershov SS, et al. Peculiarities of posthypertonic lysis in erythrocytes of several mammals. Probl Cryobiol Cryomed. 2016; 26(1): 73-83.

21.Semionova EA, Zemlyanskikh NG, Orlova NV, Shpakova NM. Antihemolytic efficiency of chlorpromazine under posthypertonic shock and glycerol removal from erythrocytes after thawing. Probl Cryobiol Cryomed. 2017; 27(1): 51-60.

22.Shpakova NM, Orlova NV, Yershov SS, Bondarenko VA. [The effect of chlorpromazine on the osmotic and temperature sensitivity of erythrocytes and on the structural-dynamic 
23. Unhale SA. Cryobiology of cell and tissue cryopreservation: experimental and theoretical analysis: thesis for the degree of Ph.D [dissertation on the internet]. Tucson: University of Arizona, 2011: 207 p. [cited 7.10.2019] Available from: https:// repository.arizona.edu/bitstream/handle/10150/202974/azu_ etd_11821_sip1_m.pdf?sequence=1\&isAllowed=y state of erythrocyte membranes]. In Goltsev AN, editor. [Current problems of cryobiology and cryomedicine.] Kharkiv: IPI\&C of NASU; 2012. p. 207-228. Russian.

23. Unhale SA. Cryobiology of cell and tissue cryopreservation: experimental and theoretical analysis: thesis for the degree of Ph.D [dissertation on the internet]. Tucson: University of Arizona, 2011, 207 p. [cited 7.10.2019] Available from: https:// repository.arizona.edu/bitstream/handle/10150/202974/azu_ etd_11821_sip1_m.pdf?sequence=1\&isAllowed=y 